\title{
Abbreviations and texts used
}

$\begin{array}{ll}\text { Eng. } & \text { English } \\ \text { FQ } & \text { The Faerie Queene } \\ \text { Fr. } & \text { French } \\ \text { Gr. } & \text { Greek } \\ \text { It. } & \text { Italian } \\ \text { L. } & \text { Latin } \\ \text { Met. } & \text { Metamorphoses } \\ \text { OE } & \text { Old English } \\ \text { OF } & \text { Old French } \\ \text { OED } & \text { Oxford English Dictionary } \\ \text { SC } & \text { The Shepheardes Calender } \\ \text { SFQ } & \text { A Supplement of the Faery Queene } \\ \text { Sp. } & \text { Spanish } \\ \text { Du Bartas } & \text { The Divine Weeks and Works of Guillaume de Saluste Sieur Du Bartas, translated by } \\ & \text { Joshua Sylvester, ed. by Susan Snyder, 2 vols (Oxford: Clarendon Press, 1979). } \\ \text { Hamilton } & \text { Edmund Spenser, The Faerie Queene, ed. by A. C. Hamilton, 2nd edn (London: } \\ & \text { Longman, 20o1). } \\ \text { Lavender } & \text { Andrew Lavender, 'An Edition of Ralph Knevett's Supplement of the Faery Queene } \\ & \text { (1635)', 2 vols (New York University doctoral dissertation, 1955). } \\ \text { Tilley } & \text { Morris Palmer Tilley, A Dictionary of the Proverbs in England in the Sixteenth } \\ & \text { and Seventeenth Centuries: A Collection of the Proverbs found in English Literature } \\ & \text { and the Dictionaries of the Period (Ann Arbor: University of Michigan Press, 1950). }\end{array}$

\section{Texts used}

All quotations from Spenser's poetical and prose works, and from the paratexts originally published with these works, are taken from The Works of Edmund Spenser: A Variorum Edition, ed. Edwin Greenlaw et al., 12 vols (Baltimore: Johns Hopkins University Press, 1932-57), and are cited by line number, page number, or book, canto, and stanza numbers, as appropriate. All quotations from Knevet's works other than the Supplement are taken from The Shorter Poems of Ralph Knevet: A Critical Edition, ed. by Amy M. Charles (Columbus, OH: Ohio State University Press, 1966), and are cited by line numbers.

References to the following sources will be made throughout the commentary by author and short title, with the exception of occasional references to early modern English translations and editions, the authors and full titles of which will be cited in each instance.

Apollodorus, The Library, Epitome, ed. and trans. by James George Frazer, 2 vols, Loeb Classical Library (London: Heinemann, 1921).

Apollonius Rhodius, Argonautica, ed. and trans. by William H. Race, Loeb Classical Library (Cambridge, MA: Harvard University Press, 2008).

Aristotle, Nicomachean Ethics, rev. edn., ed. and trans. by H. Rackham, Loeb Classical Library (Cambridge, MA: Harvard University Press, 1934).

Arrian, Anabasis of Alexander, ed. and trans. by P. A. Brunt, 2 vols, Loeb Classical Library (Cambridge, MA: Harvard University Press, 1976).

Aulus Gellius, Attic Nights, ed. and trans. by John C. Rolfe, 3 vols, Loeb Classical Library (London: Heinemann, 1952-58). 
Bede, Historical Works, ed. and trans. by J. E. King, 2 vols, Loeb Classical Library (Cambridge, MA: Harvard University Press, 1930).

[Bible], The holy bible, conteyning the old testament, and the new: newly translated out of the originall tongues (London: Richard Barker, 1611). (The King James version).

Cassius Dio, Roman History, ed. and trans. by Earnest Cary, 9 vols, Loeb Classical Library (Cambridge, MA: Harvard University Press, 1961-81).

Claudian, ed. and trans. by Maurice Platnauer, 2 vols, Loeb Classical Library (Cambridge, MA: Harvard University Press, 1963).

Diodorus Siculus, Library of History, ed. and trans. by C. H. Oldfather et al., 12 vols, Loeb Classical Library (London: Heinemann, 1946-67).

Herodotus, Histories, ed. and trans. by A. D. Godley, 4 vols (Cambridge, MA: Harvard University Press, 1961-66).

Hesiod, Homeric Hymns, Homerica, rev. edn., ed. and trans. by G. P. Goold, Loeb Classical Library (Cambridge, MA: Harvard University Press, 1936).

Homer, The Iliad, ed. and trans. by A. T. Murray, rev. by William F. Wyatt, 2nd edn., 2 vols, Loeb Classical Library (Cambridge, MA: Harvard University Press, 1999).

Homer, The Odyssey, ed. and trans. by A. T. Murray, rev. by George E. Dimock, 2nd edn., 2 vols, Loeb Classical Library (Cambridge, MA: Harvard University Press, 1995).

Horace, Odes and Epodes, ed. and trans. by Niall Rudd, Loeb Classical Library (Cambridge, MA: Harvard University Press, 2004).

Lucan, The Civil War, ed. and trans. by J. D. Duff, Loeb Classical Library (Cambridge, MA: Harvard University Press, 1957).

Ovid, Fasti, ed. and trans. by James George Frazer, rev. by G. P. Goold, Loeb Classical Library (Cambridge, MA: Harvard University Press, 1989).

Ovid, Heroides and Amores, ed. and trans. by Grant Showerman, rev. by G. P. Goold, Loeb Classical Library (Cambridge, MA: Harvard University Press, 1977).

Ovid, Metamorphoses, ed. and trans. by Frank Justus Miller, rev. by G. P. Goold, 2 vols, Loeb Classical Library (Cambridge, MA: Harvard University Press, 1977-84).

Pausanias, Description of Greece, ed. and trans. by W. H. S. Jones, 5 vols, Loeb Classical Library (Cambridge, MA: Harvard University Press, 1916-35).

Pliny, Natural History, ed. and trans. by H. Rackham and W. H. S. Jones, 10 vols, Loeb Classical Library (London: Heinemann, 1956-63).

Quintus Curtius, History of Alexander, ed. and trans. by John C. Rolfe, 2 vols, Loeb Classical Library (Cambridge, MA: Harvard University Press, 1956-61).

Seneca, Epistles, ed. and trans. by Richard M. Gummere, 3 vols, Loeb Classical Library (Cambridge, MA: Harvard University Press, 1917-25).

Seneca, Moral Essays, ed. and trans. by John W. Basore, 3 vols, Loeb Classical Library (Cambridge, MA: Harvard University Press, 1928-35).

William Shakespeare, The Complete Works, ed. by Stanley Wells and Gary Taylor (Oxford: Clarendon Press, 1986).

Strabo, Geography, ed. and trans. by Horace Leonard Jones, 8 vols, Loeb Classical Library (London: Heinemann, 1917-32).

Tacitus, Agricola, Germania, Dialogus, rev. edn., ed. and trans. by R. M. Ogilvie et al., Loeb Classical Library (Cambridge, MA: Harvard University Press, 1970).

Valerius Maximus, Memorable Doings and Sayings, ed. and trans. by D. R. Shackleton Bailey, Loeb Classical Library (Cambridge, MA: Harvard University Press, 2000).

Virgil, Eclogues, Georgics, Aeneid, Minor Poems, rev. edn., ed. and trans. by H. R. Fairclough, 2 vols., Loeb Classical Library (Cambridge, MA: Harvard University Press, 1934-35). 